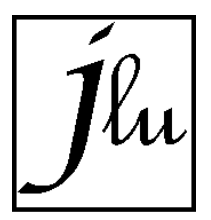

Jurnal Luminous:

Riset Ilmiah Pendidikan Fisika

Vol. 1 No. 1 (2020) 51-59
E-ISSN 2715-6990

P-ISSN 2715-9582

Januari 2020

https://jurnal.univpgri-

palembang.ac.id/index.php/luminous

\title{
PENGGUNAAN ADAPTASI INSTRUMEN EPEPECT UNTUK MEMBEDAKAN SISWA YANG MENGALAMI MISKONSEPSI DAN MENGETAHUI TINGKAT MISKONSEPSI SISWA MA KELAS XII PADA KONSEP MEDAN LISTRIK, POTENSIAL LISTRIK DAN ENERGI POTENSIAL LISTRIK

\author{
Muhammad Iqbal ${ }^{1}$, Achmad Samsudin $^{2}$, Ridwan Efendi ${ }^{3}$ \\ 1,2,3 Departemen Pendidikan Fisika, Fakultas Pendidikan Matematika dan IImu Pengetahuan Alam \\ Universitas Pendidikan Indonesia (UPI) \\ 1'Mohammad.i@student.upi.edu, ²achmadsamsudin@upi.edu, ${ }^{3}$ ridwanefendi@upi.edu
}

\begin{abstract}
Abstrak
Tujuan penelitian adalah untuk membedakan siswa yang mengalami miskonsepsi dan mengetahui tingkat miskonsepsi siswa terhadap konsep medan listrik, potensial listrik, dan energi potensial listrik dengan menggunakan adaptasi instrumen The Electric Potential and Electric Potential Energy Concept Test (EPEPECT). EPEPECT merupakan instrumen yang berupa pilihan ganda disertai dengan tingkat keyakinan pada tiap nomornya. Adaptasi yang dilakukan adalah dengan menambahkan opsi pada pilihan ganda, sehingga tidak menggunakan reasoning terbuka dengan tujuan siswa tidak memberikan jawaban diluar opsi yang diberikan. Penelitian menggunakan metode survei yang termasuk kedalam pendekatan kuantitatif noneksperimen. Teknik pengambilan sampel berupa sampel bertujuan (purposive sample). Sampel penelitian 164 siswa yang berada di empat sekolah Madrasah Aliyah (MA) di Kabupaten dan Kota Cirebon. Untuk membedakan siswa yang mengalami miskonsepsi dan mengetahui tingkat miskonsepsi siswa, dilakukan perhitungan dengan merujuk pada format respons siswa yang terdapat pada Tesis Vatansever. Penelitian menggunakan 5 soal yang telah di adaptasi yang mencakup konsep medan listrik, potensial listrik dan energi potensial listrik. Berdasarkan penelitian, kecenderungan jawaban siswa yang mengarah ke miskonsepsi terdapat pada kategori greatest possible misconception, sebesar $32 \%$ untuk konsep medan listrik, sedangkan sebesar $31 \%$ pada konsep potensial listrik dan konsep energi potensial listrik sebesar $23 \%$. Tingkat miskonsepsi siswa, sebanyak 75 siswa terjadi miskonsepsi rendah (low misconception) yakni pada rentang 0-14 dan 89 siswa terjadi miskonsepsi tinggi (high misconception) pada rentang 16-28.
\end{abstract}

Kata kunci : tingkat miskonsepsi, EPEPECT, konsep Listrik

(C) 2020 Pendidikan Fisika FKIP UPGRI Palembang

\section{PENDAHULUAN}

Berbicara fisika tak lepas kaitannya dengan cabang ilmu sains, yang kerap bersinggungan dengan kehidupan manusia. Karena jika dilihat sifatnya fisika sendiri merupakan sains dalam bentuk fisik, sehingga fisika merupakan sains paling jelas dirasakan oleh manusia. Fisika merupakan ilmu yang empiris yang tidak akan mampu diselesaikan tanpa memahami konsepnya terlebih dahulu. Menurut Rusilowati (2006, hlm. 100) sifat mata pelajaran fisika salah satunya adalah bersyarat artinya setiap konsep baru adakalanya 
menuntut prasyarat pemahaman atas konsep sebelumnya. Sehingga butuh pemahaman lebih untuk memaknai atau memahami konsep dalam mempelajari fisika yang benar, karena akan selalu beriringan antara konsep yang satu dengan yang lainnya. Bila konsep awal salah maka selanjutnya akan salah pula memahami konsep selanjutnya. Maka dari itu memahami konsep adalah langkah awal untuk menyelesaikan persoalan-persoalan yang terdapat di dalam fisika.

Keberhasilan peserta didik dalam mempelajari materi fisika tidak hanya ditentukan oleh seberapa pandai peserta didik tersebut mengerjakan soal-soal fisika tetapi juga seberapa dalam peserta didik memahami dan menguasai konsep dari materi fisika yang sedang dipelajari. Menurut Setiyawan, Sutarto \& Subiki (2012, hlm. 206) fisika tidak hanya berisi tentang pengetahuan untuk dihafal, akan tetapi dalam fisika lebih ditekankan pada terbentuknya proses pengetahuan dan penguasaan konsep di benak siswa dalam proses belajar mengajar. Begitu pentingnya pemahaman akan suatu konep tertentu, Sudijono (2012, hlm. 50) dalam bukunya yang berjudul "Pengantar Evaluasi Pendidikan", mengatakan bahwa pemahaman (comprehension) adalah kemampuan seseorang untuk mengerti atau memahami sesuatu setelah sesuatu itu diketahui dan diingat. Pemahaman merupakan jenjang kemampuan berpikir yang setingkat lebih tinggi dari ingatan atau hafalan.

Pemahaman adalah tingkatan kemampuan yang mengharapkan seseorang mampu memahami arti atau konsep, situasi serta fakta yang diketahuinya. Kocakulah dalam jurnalnya (2010, hlm. 1) mengatakan bahwa peserta didik dalam kehidupan sehari-hari berinteraksi dengan dunia fisika, akibat interaksi tersebut peserta didik datang ke kelas dilengkapi dengan ide-ide tertentu dan gagasan tentang dunia fisika. Oleh sebab itu, pentingnya pemahaman siswa terhadap konsep tertentu agar tidak terjadi miskonsepsi.

Suparno (2013, hlm. 11) mengatakan bahwa miskonsepsi banyak terjadi dalam bidang fisika. Wandersee, Mintzes, dan Novak (dalam Suparno, 2006, hal. 6), dalam artikelnya mengenai Research on Alternative Conceotions in Science, menjelaskan bahwa konsep alternatif atau miskonsepsi terjadi dalam semua bidang fisika. Dari 700 studi mengenai konsep alternatif bidang fisika, ada 300 yang meneliti tentang miskonsepsi dalam mekanika; 159 tentang listrik; 70 tentang panas, optika, dan sifat-sifat materi; 35 tentang bumi dan antariksa; serta 10 studi mengenai fisika modern.

Peneliti mencoba mengetahui tingkat miskonsepsi yang terjadi pada konsep listrik. Vatansever (2006, hlm. 26), dalam tesisnya mengungkapkan bahwa Electricity due to its nature is the most abstract concept in physics yang artinya sifat dasar kelistrikan merupakan konsep yang sangat abstrak dalam fisika. Ada banyak alasan mengapa konsep kelistrikan sangat membingungkan bagi siswa. Alasan yang paling utama adalah fisika memiliki penjelasan yang konkret dan unik pada materi kelistrikan.

Miskonsepsi menjadi persoalan yang serius di dunia pendidikan. Menurut Van den Berg (1991, hlm. 10) menyatakan bahwa miskonsepsi merupakan konsepsi (tafsiran 
perorangan dari suatu konsep ilmu) siswa bertentangan dengan konsepsi para fisikawan. Senada dengan hal tersebut Suparno (2013, hlm. 4), mengungkapkan bahwa miskonsepsi menunjuk pada suatu konsep yang tidak sesuai dengan pengertian ilmiah atau pengertian yang diterima para pakar dalam bidang itu. Berdasarkan pengertian diatas miskonsepsi adalah suatu pemahaman konsep yang keliru atau berbeda terhadap konsep tertentu yang dikemukakan oleh para ahli. Miskonsepsi hendaknya dapat dideteksi sedini mungkin agar tidak terjadi secara terus menerus dan dibawa hingga kejenjang yang lebih tinggi.

Banyak cara yang dilakukan untuk mendeteksi miskonsepsi yang terjadi pada siswa. Menurut Suparno (2013, hlm. 121-128) cara-cara mengidentifikasi atau mendeteksi miskonsepsi dapat dilakukan dengan berbagai cara, antara lain dengan menggunakan peta konsep (concept maps), tes multiple choise, tes esai tertulis, wawancara diagnosis, diskusi dalam kelas dan praktikum dengan tanya jawab.

Cara yang digunakan untuk mengidentifikasi miskonsepsi dalam penelitian ini adalah menggunakan pilihan ganda dengan tingkat keyakinan pada tiap soalnya, instrumen yang digunakan merujuk pada tesis Vatansever yakni menggunakan The Electric Potential and Electric Potential Energy Concept Test (EPEPECT) yang telah diadaptasi, instrumen tersebut dibuat dengan tujuan untuk mengetahui tingkat miskonsepsi siswa pada materi potensial listrik dan energi potensial listrik.

Maka dari itu berdasarkan pemaparan tersebut peneliti mencoba menganalisis tingkat miskonsepsi siswa pada konsep medan listrik, potensial listrik dan energi potensial listrik pada kelas XII. Penentuan kelas XII karena peneliti menganggap pada kelas XII materi mengenai konsep tersebut sudah diajarkan secara mendalam.

\section{METODE}

Metode yang digunakan dalam penelitian adalah metode survei yang termasuk kedalam pendekatan kuantitatif non-eksperimen. Penelitian survei adalah suatu metode penelitian yang mendeskripsikan secara kuantitatif (angka-angka) kecenderungankecenderungan, perilaku-perilaku, atau opiniopini dari suatu populasi dengan meneliti sampel populasi tersebut (Cresswell, 2013, hlm. 216).

Partisipan yang terlibat pada penelitian ini adalah seluruh kelas XII IPA di empat sekolah Madrasah Aliyah Negeri yang terdapat di Kabupaten dan Kota Cirebon, jumlah partisipan sebanyak 414 siswa.

Teknik penelitian yang digunakan adalah sample bertujuan (purposive sample). Yakni teknik pengambilan sampel yang tidak memberi peluang atau kesempatan sama bagi setiap unsur atau anggota populasi untuk dipilih menjadi sampel (Sugiyono, 2010, hlm. 84). Peneliti menentukan banyaknya sampel berdasarkan tingkat kepercayaan atau ketelitian hasil penelitian.

Berdasarkan petimbangan waktu, tenaga dan dana peneliti menentukan jumlah sampel dengan tingkat kepercayaan $90 \%$ dengan taraf kesalahan 10\%. Banyaknya sampel ditentukan dengan menggunakan tabel yang 
dikembangkan oleh Isaac dan Michael berdasarkan rumus yang dikembangkan oleh keduanya (Sugiyono, 2010, hlm. 86-87).

Populasi siswa kelas XII dari empat sekolah Madrasah Aliyah Negeri yang diteliti sebanyak 414 orang. Berdasarkan tabel yang dikembangkan oleh Isaac dan Michael maka jumlah sampel dari populasi 414 orang kurang lebih sekitar 164 orang, banyaknya sampel berdasarkan rumus tersebut diberi lambang $\left(\mathrm{N}_{\text {tabel }}\right)$, untuk menentukan banyaknya sampel dari tiap sekolah dapat ditentukan dengan menggunakan rumus:

Dengan :

$$
\mathrm{N}_{\mathrm{s}}=\frac{N}{\Sigma N} \times \mathrm{N}_{\text {tabel }}
$$

$\mathrm{N}_{\mathrm{s}}=$ Jumlah sampel di tiap sekolah

$\mathrm{N}$ = Jumlah siswa ditiap sekolah

$\mathrm{N}_{\text {tabel }}=$ jumlah sampel berdasarkan tabel

Sehingga jumlah sampel tiap sekolah dapat dilihat pada tabel 1 .

\section{Tabel 1. Jumlah Sampel Tiap Sekolah}

\begin{tabular}{lcc}
\hline Nama Sekolah & $\begin{array}{c}\text { Jumlah } \\
\text { Siswa } \\
\text { Kelas XII } \\
(\mathbf{N})\end{array}$ & $\begin{array}{c}\text { Jumlah } \\
\text { Sampel } \\
(\mathbf{N s})\end{array}$ \\
\hline MA N 1 Cirebon & 78 orang & 31 orang \\
\hline MA N 2 Cirebon & 106 orang & 42 orang \\
\hline MA N 3 Cirebon & 77 orang & 30 orang \\
\hline MA N Ciwaringin & 153 orang & 61 orang \\
\hline Jumlah Total $(\Sigma)$ & $\mathbf{4 1 4}$ orang & 164 orang \\
\hline
\end{tabular}

Prosedur penelitian yang dilakukan terbagi kedalam tiga tahap, diantaranya tahap persiapan, tahap pelaksanaan dan tahap ahir penelitian.

\section{Tahap Persiapan Penelitian}

Tahap ini diawali dengan mengadaptasi yakni menambahkan pilihan jawaban pada option E sehingga menjadi lima jawaban, peneliti tidak menggunakan reasoning terbuka dengan beberapa pertimbangan. Langkah selanjutnya soal di-judgement oleh dua orang dosen ahli dibidangnya (kelistrikan) untuk menentukan sesuai atau tidak berdasarkan indikator pencapaian kompetensi, dan susunan kalimat yang terdapat pada soal.

2. Tahap Pelaksanaan Penelitian

Penelitian dilakukan di empat sekolah Madrasah Aliyah Negeri (MAN) di Kabupaten/Kota Cirebon, Jawa Barat.

3. Tahap Akhir Penelitian

Tahap ahir penelitian, peneliti melakukan pengolahan data hasil penelitian yakni menggunakan rujukan dari ketentuan yang terdapat pada Tesis Vatansever halaman 39-40. Dapat disimpulkan pada Tabel 2 berikut.

\section{Tabel 2. Respons Siswa Terhadap Peluang Terjadinya Miskonsepsi}

\begin{tabular}{lcl}
\hline $\begin{array}{c}\text { Jawaban dan } \\
\text { Respons Siswa } \\
\text { Terhadap Soal }\end{array}$ & Kode & $\begin{array}{l}\text { Peluang } \\
\text { Terjadi } \\
\text { Miskonsepsi }\end{array}$ \\
\hline $\begin{array}{l}\text { Benar atau } \\
\text { Salah+Tidak Tahu } \\
\text { Benar+Yakin }\end{array}$ & 0 & $\begin{array}{l}\text { no existing } \\
\text { misconception }\end{array}$ \\
\hline Benar+Tidak Yakin & 1 & $\begin{array}{l}\text { existing } \\
\text { misconception }\end{array}$ \\
\hline Salah+Tidak Yakin & 2 & $\begin{array}{l}\text { relatively } \\
\text { greater } \\
\text { misconception }\end{array}$ \\
\hline Salah+Yakin & 3 & $\begin{array}{l}\text { greatest } \\
\text { possible } \\
\text { misconception }\end{array}$ \\
\hline
\end{tabular}

Setelah semua respons siswa dimasukkan ke dalam kategori pada Tabel 2, selanjutnya untuk menghitung tingkat miskonsepsi siswa dilakukan konversi ke skala Vatansever. Konversi dapat dilakukan dengan mengetahui terlebih dahulu jumlah soal yang 
akan di ujikan. Perhitungannya dapat dilihat pada Gambar 1.

\section{Gambar 1. Konversi Skala Vatansever}

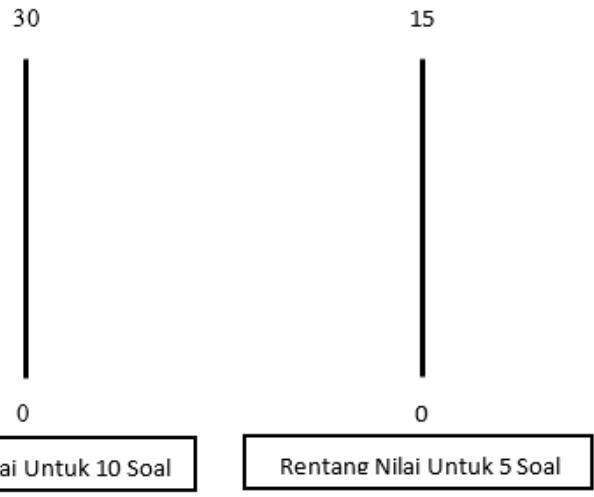

Ambil batas maksimal dari 10 soal dan 5 soal, kemudian bandingkan dan dikali dengan jumlah yang didapat pada tingkat miskonsepsi yang akan dicari. Sehingga menjadi:

$$
\frac{30}{15} \times N
$$

atau dapat disederhanakan menjadi

$$
2 \times N
$$

dimana:

$\mathrm{N}=$ jumlah yang didapat pada tingkat miskonsepsi yang akan dicari.

Dengan perhitungan tersebut, akan mempermudah untuk menyetarakan nilai 5 soal dengan 10 soal yang telah ditetapkan oleh Vatansever.

\section{HASIL DAN PEMBAHASAN}

\section{Rata-Rata Nilai Miskonsepsi Siswa}

Pengambilan data penelitian dilakukan sekali dengan menggunakan tes berupa pilihan ganda berjumlah 5 soal. Berdasarkan penelitian, jawaban siswa (benar/salah) beserta tingkat keyakinan menjawab soal dapat dilihat pada Tabel 3.

Tabel 3. Jawaban Siswa Beserta Tingkat

\begin{tabular}{|c|c|c|c|c|c|c|}
\hline \multirow{2}{*}{ No } & & $\begin{array}{l}\text { so existi } \\
\text { sconcep }\end{array}$ & & $\begin{array}{l}\text { existing } \\
\text { misconc } \\
\text { eption }\end{array}$ & \multirow{2}{*}{$\begin{array}{l}\text { Relativ } \\
\quad \text { ely } \\
\text { greater } \\
\text { miscon } \\
\text { ception } \\
\text { (S+TY) }\end{array}$} & \multirow{2}{*}{$\begin{array}{c}\text { Greatest } \\
\text { possible } \\
\text { misconc } \\
\text { eption } \\
(\mathrm{S}+\mathrm{Y})\end{array}$} \\
\hline & $\mathrm{B}+\mathrm{Y}$ & $\mathrm{B}+\mathrm{TT}$ & $\mathrm{S}+\mathrm{TT}$ & $(\mathrm{B}+\mathrm{TY})$ & & \\
\hline 1 & 11 & 6 & 30 & 12 & 54 & 51 \\
\hline 2 & 26 & 3 & 13 & 12 & 45 & 65 \\
\hline 3 & 16 & 8 & 24 & 16 & 49 & 51 \\
\hline 4 & 43 & 9 & 16 & 22 & 30 & 44 \\
\hline 5 & 31 & 15 & 23 & 24 & 34 & 37 \\
\hline
\end{tabular}
Keyakinan Pada Tiap Kategori Miskonsepsi

Keterangan:

B:Benar, S:Salah, Y:Yakin, TT:Tidak Tahu, TY:Tidak Yakin.

Setelah semuanya dikelompokkan berdasarkan kategorinya, maka selanjutnya mengelompokkan berdasarkan konsep medan listrik, potensial listrik dan energi potensial listrik. Setelah dilakukan perhitungan, maka dapat dilihat pada Gambar 2, mengenai banyaknya siswa yang mengalami miskonsepsi pada tiap kategorinya. 


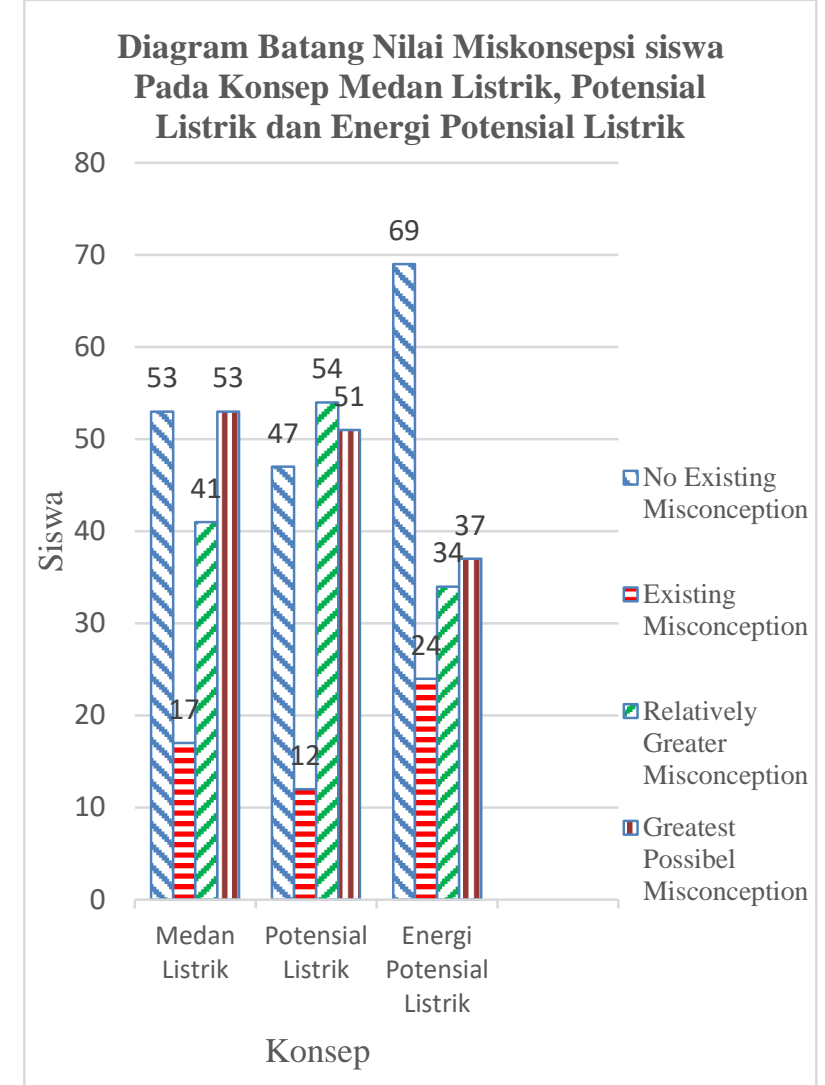

\section{Gambar 2. Diagram Batang rata-rata Nilai miskonsepsi Siswa Pada Konsep Potensial Listrik dan Energi Potensial Listrik}

Berdasarkan Gambar 2, untuk konsep medan listrik, banyaknya siswa yang tidak mengalamami miskonsepsi sebanyak 53 siswa, sedangkan kategori existing misconception sebanyak 17 siswa, untuk kategori relatively greater misconception sebanyak 41 siswa, dan pada kategori greatest possible misconception sebanyak 53 siswa.

Miskonsepsi yang terjadi pada siswa untuk konsep medan listrik yakni terdapat pada garisgaris medan listrik dari suatu dipol dimana sebagian besar siswa menjawab garis medan listrik positif secara radial menuju kedalam sedangkan muatan negatif secara radial menuju ke luar. Secara literatur garis-garis medan listrik dari suatu dipol bila letaknya sangat dekat dengan muatan positif, garis-garis mengarah radial keluar. Pada titik yang sangat dekat dengan muatan negatif, garis-garis medan mengarah radial kedalam (Tipler, 2001, hlm. 21).

Sedangkan pada konsep potensial listrik sebanyak 47 siswa tidak terjadi miskonsepsi (no existing misconception), sedangkan kategori existing misconception sebanyak 12 siswa, pada kategori relatively greater misconception sebanyak 54 siswa, dan pada kategori greatest possible misconception sebanyak 51 siswa.

Miskonsepsi yang terjadi pada siswa untuk konsep potensial listrik adalah pada garis ekipoensial, kebanyakan siswa menjawab jika yang dinamakan beda potensial yang sama adalah suatu titik yang letaknya berbeda dan tidak berpasangan yang terdapat pada garis ekipotensial yang berbeda

Pada konsep energi potensial listrik, sebanyak 69 siswa termasuk kedalam kategori no existing misconception, pada kategori existing misconception sebanyak 24 siswa, sedangkan pada kategori relatively greater misconception sebanyak 34 siswa, dan pada kategori greatest possible misconception sebanyak 37 siswa.

Miskonsepsi yang terjadi pada siswa untuk konsep energi potensial listrik adalah tidak ada keterkaitan atau hubungan antara potensial listrik dengan energi potensial listrik. Berdasarkan literatur yang ada energi potensial listrik bergantung dengan potensial listrik, ketika muatan diletakkan pada medan listrik seragam, garis medan listrik menunjuk kearah potensial rendah. Maka perubahan energi potensialnya 
akan berkurang sedangkan energi kinetiknya bertambah (Tipler, 2001, hlm. 75)

Hal tersebut disebabkan oleh beberapa faktor, menurut Suparno (2013, hlm. 29), menyatakan bahwa secara garis besar penyebab miskonsepsi dapat diringkas dalam lima kelompok, yaitu: siswa, guru, buku teks, konsteks dan metode mengajar. Pada dasarnya pelajaran fisika mengungkap fenomenafenomena alam yang terjadi, akan tetapi tuntutan sekolah dan evaluasi ahir atau yang sekarang kita kenal dengan Ujian Nasioanl (UN), jika dilihat pada soal Ujian Nasional bidang fisika, porsi soal yang berkaitan dengan konsep berkisar antara 6 hingga 7 soal dari 40 soal yang di ujikan. Maka tidaklah menutup kemungkinan sebagaian pendidik mengajarkan konsep dengan porsi yang sedikit pula, padahal konsep merupakan ide dasar atau pengetahuan awal yang sangat penting untuk memaknai dan memahami persoalan khususnya pada konsep medan listrik, potensial listrik dan energi potensial listrik.

\section{Tingkat Miskonsepsi Siswa}

Untuk perhitungan tingkat miskonsepsi, Vatansever (2006, hlm. 39) dalam tesisnya memberikan rentang antara 0-30, skor rendah mengindikasikan kecil terjadi miskonsepsi (low misconception) memiliki rentang dari 0-15, sedangkan skor tinggi berarti pasti terjadi miskonsepsi (high misconception) memiliki rentang dari 16-30.

Berdasarkan perhitungan maka didapatkan untuk low misconception sebanyak 75 siswa, sedangkan untuk high misconception sebanyak 89 siswa. Hasil perhitungan tersebut dapat direpresentasikan pada Gambar 3.

\section{Gambar 3. Diagram Batang Hasil \\ Perhitungan Tingkat Miskonsepsi Siswa.}

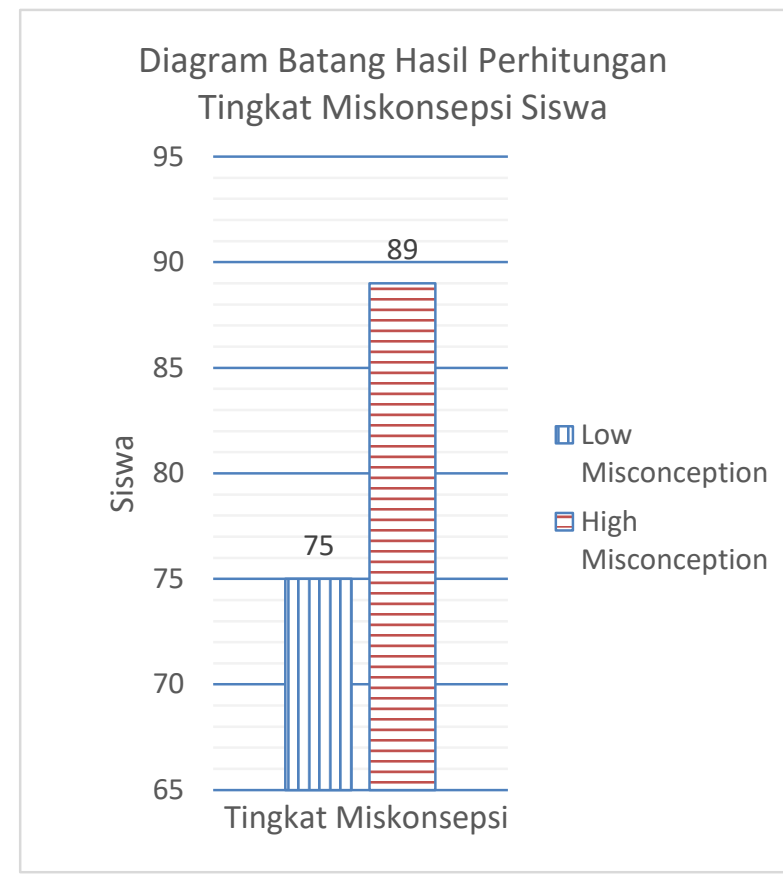

Berdasarkan hasil perhitungan tingkat miskonsepsi siswa pada tiap-tiap siswa, didapatkan rentang tingkat miskonsepsinya dari 0 hingga 28.

Banyak hal yang menyebabkan siswa mengalami miskonsepsi bisa ditimbulkan dari diri siswa sendiri, bisa juga dari pengajar, buku teks, pergaulan sehari-hari (konteks) dan metode mengajar. Van den Berg (1991, hlm. 13) menyimpulkan bahwa banyak konsepsi (tafsiran perorangan dari suatu konsep ilmu) dan miskonsepsi anak terbentuk pada masa anak dalam interaksi otak dengan alam, ataupun bahwa konsepsi/miskonsepsi merupakan pembawaan manusia. Sedangkan menurut Suparno (2013, hlm. 34), miskonsepsi dalam bidang fisika paling banyak berasal dari diri siswa sendiri. Miskonsepsi yang berasal dari siswa dapat dikelompokkan dengan beberapa hal, antara lain: konsepsi awal siswa, pemikiran 
asosiatif, reasoning yang tidak lengkap/salah dll. Sehingga tingkat miskonsepsi yang didapat mengindikasikan siswa benar-benar mengalami miskonsepsi.

\section{SIMPULAN}

Banyaknya siswa yang mengalami miskonsepsi atau yang tergolong kedalam kategori greatest possible misconception pada konsep medan listrik sebanyak 53 siswa atau sekitar $32 \%$, sedangkan pada konsep potensial listrik sebanyak 51 siswa atau sekitar 31\% siswa, dan konsep energi potensial listrik sebanyak 37 siswa atau sekitar $23 \%$.

Rentang tingkat miskonsepsi siswa untuk soal yang diujikan dari 0 hingga 28. Pada rentang tersebut, sebanyak 75 siswa termasuk kedalam tingkat miskonsepsi rendah (low misconception), sedangkan sebanyak 89 siswa mengalami tingkat miskonsepsi tinggi (high misconception)

Berdasarkan hasil penelitian, jika dihubungkan antara jawaban siswa yang mengalami miskonsepsi dengan tingkat miskonsepsi siswa, terdapat hubungan satu sama lain. Jika dikelompokkan banyaknya siswa yang mengalami tingkat miskonsepsi rendah (low misconception) maka banyak siswa yang tidak mengalami miskonsepsi. Begitu pula sebaliknya, jika pada tingkat miskonsepsi tinggi (high misconception) maka banyak siswa yang mengalami miskonsepsi.

\section{DAFTAR PUSTAKA}

Cresswell, John W. (2013). Research Design Pendekatan Kualitatif, Kuantitatif, dan Mixed. Yogyakarta : Pustaka Pelajar

Kocakulah, M.S. dan Kural M. (2010). Investigation of conceptual change about double-slit interference in secondary school physics. International Journal of Environmental \& Science Education, 5(4), hlm. 435-460.

Rusilowati, A. (2006). Profil kesulitan belajar fisika pokok bahasan kelistrikan siswa SMA di Kota Semarang. Jurnal Pendidikan Fisika Indonesia, 4(2), hIm. 100-106

Setiyawan, R. T., Sutarto \& Subiki. (2012). Meningkatkan aktivitas dan hasil belajar fisika dengan metode demonstrasi yang dilengkapi media lingkungan pada siswa kelas VIIB SMP Negeri 13 Jember. Jurnal Pembelajaran Fisika, 1(2), hlm. 206-211

Sudijono, A. (2012). Pengantar Evaluasi Pendidikan. Jakarta. Jakarta : PT Rajagrafindo Persada.

Sugiyono. (2010). Metode Penelitian Kuantitatif, Kualitatif dan R\&D. Bandung : Alfabeta.

Suparno, P. (2013). Miskonsepsi dan Perubahan Konsep dalam Pendidikan Fisika. Jakarta : Grasindo.

Tipler. P. A. (2001). Fisika untuk Sains dan Teknik. Jakarta : Erlangga.

Van den Berg, E. (1991). Miskonsepsi Fisika dan Remediasi. Salatiga : Universitas Kristen Satya Wacana. 
Vatansever, O. (2006). Effectiveness of conceptual change instruction on overcoming students' misconceptions of electric field, electric potential and electric potential energy at tenth grade level.

(Tesis).

Tersedia: http://etd.lib.metu.edu.tr/upload/126079 20/index.pdf [10 Juni 2014] 